\title{
Part-time and Limited-term Faculty in Alberta's Colleges
}

\section{BOB BARNETSON*}

Edmonton, Alberta

\section{ABSTRACT}

This paper argues that the number of part-time and limited-term faculty in Alberta's (Canada) public colleges and technical institutes and their substantially different employment conditions indicate the existence of a dual labour market at five institutions. Further analysis demonstrates that women disproportionately receive part-time and limited-term appointments.

\section{RÉSUMÉ}

Cet article démontre que le nombre de professeurs à temps partiel et à contrat dans les collèges publiques et les institutions techniques en Alberta (Canada), de même que leurs conditions d'embauche qui diffèrent grandement, soutiennent l'existence d'un double marché du travail dans cinq institutions. Des analyses plus approfondies démontrent que les femmes reçoivent, de façon disproportionnée, des désignations d'emploi à temps partiel et à durée limitée.

* The author would like to acknowledge the helpful comments of Marianne Sorensen (Athabasca University) and two anonymous reviewers in the preparation of this paper. 


\section{INTRODUCTION}

Anecdotal reports regarding the growing use and gendered natured of part-time and limited-term faculty appointments in Alberta's public colleges and technical institutes resulted in a September 1999 study of nonregular instructional appointments (NRIAs). This study determined that, provincially, $44.0 \%$ of faculty members were employed on a part-time basis (i.e., carry less than $100 \%$ of the normal workload) and $50.4 \%$ were employed on a limited-term basis (i.e., are employed on fixed-term contracts). This study also confirmed that women disproportionately received NRIAs and that a dual labour market existed at 5 of 17 institutions.

\section{BACKGROUND}

Alberta's 115,000 full-time equivalent postsecondary students are served by a publicly funded postsecondary education system that comprises four universities, fifteen two-year colleges, two technical institutes and the Banff Centre. Albertans can also access five church-affiliated university colleges that grant degrees, a large apprenticeship training system and over 100 private vocational schools. Government fiscal transfers to institutions totaled $\$ 996$ million in 1999 (Alberta Learning, 2000).

As outlined in Barnetson and Boberg (2000), government policy has pressured Alberta's postsecondary institutions to increase instructional efficiency and flexibility in order to lower costs to the taxpayer and match programming to labour market needs. Beginning in 1994, Alberta's government reduced its funding to postsecondary institutions by $21 \%$ over three years (AECD, 1994). Combined with enrollment increases and sluggish funding growth in the 1980s, real-dollar, perstudent funding declined by $50.4 \%$ between $1982(\$ 12,478)$ and 1999 $(\$ 6,184)$. This decline was reduced to $34.9 \%$ by rising tuition revenue. The resulting financial pressure was in part managed by a $5.9 \%$ decline in average real-dollar salary and benefit payments to full-time faculty between 1994 and 1998 (AECD, 1995; AECD, 1999).

Since the establishment of Lethbridge Community College in 1957, Alberta's college sector has grown to include one art college, three agricultural colleges, four vocational colleges, nine community/regional 
colleges and two technical institutes. Each institution offers a wide range of programming that can include university transfer, academic upgrading, two-year career and technical diplomas, community education, apprenticeship training and four-year applied degrees. The college and institute system as of September 1999 is summarized in Table 1.

Alberta's colleges differ from the Ontario's Colleges of Applied Arts and Technology in that Alberta's institutions are more diverse and have a large commitment to university-transfer programs. Alberta's colleges also differ from those in British Columbia in that Alberta's colleges have been largely unsuccessful in gaining degree-granting status (Dennison, 1995; Dennison \& Gallagher, 1986).

The operation of colleges and institutes is governed by the Colleges Act and the Technical Institutes Act respectively. These acts mandate a form of bicameral governance and each institution is managed by a government-appointed Board of Governors. Academic decisions are vetted through an academic council that makes recommendations to the Board of Governors. The advisory role of academic councils means faculty have less control over academic matters than at universities - a Canada-wide characteristic in public colleges (Dennison \& Gallagher, 1986). This situation heightens the importance of collective agreements as a way faculty can constrain administrative decision-making.

The Acts state that the Employment Standards Code and the Labour Relations Code do not apply to the negotiation and enforcement of a collective agreement between Boards and academic staff associations. In their place, the Acts stipulate the minimum content of collective agreements and deemed provisions for resolving interest and rights disputes (via binding arbitration) if an institution's collective agreement is silent on the matter. The academic staff associations at each institution have formed a provincial organization called the Alberta Colleges \& Institutes Faculties Association (ACIFA). ACIFA provides advice and assistance in collective bargaining but each association bargains independently (as opposed to the province-wide bargaining that occurs at colleges in British Columbia, Saskatchewan and Ontario). 
Table 1

Alberta's Colleges and Institutes

Calgary

741.8

2936.2

834.4

1412.6

6800.5

1261.6

1286.1

3761.1

2043.0

6307.5

9423.1

3481.6

1073.4

1176.8

923.4

3450.2

9124.7
Degree-granting

Adult Upgrading/Career

Diploma/Apprenticeship

University Transfer

University Transfer

Diploma/Apprenticeship

Diploma/Apprenticeship

Diploma/University Transfer

Diploma/University Transfer

University Transfer

Diploma/Apprenticeship

Adult Upgrading/Career

Adult Upgrading/Career

Diploma/Apprenticeship

Adult Upgrading/Career

University Transfer

Diploma/Apprenticeship

Source: AECD, 1999

Note: Student numbers are full-load equivalents (FLEs) for $1997 / 98$ 


\section{PURPOSE AND METHODOLOGY}

In March 1999, representatives from five academic staff associations requested that ACIFA study the growing use of part-time and limitedterm faculty with specific attention to reports that women disproportionately received these non-regular instructional appointments (NRIAs). Four questions emerged from discussion:

1. What percentage of faculty are employed on a part-time basis at each institution?

2. What percentage of faculty are employed on a limited-term basis at each institution?

3. Do women disproportionately receive part-time and/or limited-term appointments?

4. Does a dual labour market exist at any institutions?

To answer the first three questions, ACIFA gathered information regarding the number and type of instructional appointments from each college using Alberta's Freedom of Information and Protection of Privacy Act (Barnetson, 2000). During data gathering, the terms and conditions of employment were described in two different ways. First, the workload (i.e., whether a job is full-time or part-time) of all faculty was examined. Second, the duration of employment (i.e., whether a job is permanent or limited-term) was examined. This approach deviated from earlier studies (e.g., CIEA, 1992; Gappa and Leslie, 1993) that focus exclusively on workload. By examining both workload and employment duration, a more complete picture of employment conditions emerge that illustrates, for example, the large number of full-time employees who are employed on a limited-term (i.e., temporary) basis.

To answer the fourth question, the percentage of part-time and limited-term appointments at each institution was examined. If the institution employed more than $25 \%$ of its faculty on a part-time and limited-term basis, that institution's collective agreement was examined to determine if the pro-rata remuneration of part-time faculty was significantly lower than for full-time faculty. If this was the case, then a dual labour market was deemed to exist. Further information regarding this approach (and its limitations) is presented along with the results below. 


\section{RESULTS}

This section outlines the number of part-time and limited-term faculty employed in Alberta's colleges and institutes in September 1999. This section also compares the percentages of women and men receiving part-time and limited-term appointments. Finally, this section reports on the emergence of a dual labour market at 5 of 17 institutions.

\section{Part-time employment in Alberta's colleges and institutes}

The use of part-time faculty has received extensive treatment with the majority of the literature being descriptive work emanating from the United States and focusing on part-time appointments in universities (e.g., Gappa \& Leslie, 1993, 1997; Leslie, 1998; Leslie, Kellams, \& Gunne, 1982; Tuckman, 1979). A number of Canadian studies exist but most focus on university academics (e.g., Council of Ontario Universities, 1991; Lundy \& Warme, 1985; Rajagopal \& Farr, 1989; Rajagopal \& Lin, 1996) while two studies (CIEA, 1992; Prindle, 1998) address part-time faculty in community colleges.

The percentage of U.S. community college faculty who are part-time increased from 38\% in 1968 to 58\% in 1993 (Robinson, 1994; Roueche, Roueche, \& Milliron, 1995). Longitudinal data in Canada are not available, but in 1997-98, 52.1\% of educational staff in Canada's colleges and vocational schools were employed on a part-time basis (Statistics Canada, 2000b). This percentage differs substantially from the $18.3 \%$ of all Canadian employees who worked on a part-time basis in 1999 (Statistics Canada, 2000a). The higher proportion of part-time employees in colleges may reflect that: (1) colleges have large career-training programs and use professionals as instructors, (2) colleges are meant to be responsive to social needs and hiring part-time (as well as temporary) staff increases programming flexibility, and (3) part-time faculty can reduce the cost of providing instruction.

In this study, faculty members were classified as working full-time (i.e., carrying $100 \%$ of the normal workload assigned to faculty members) or as working part-time (i.e., carrying less than $100 \%$ of a normal workload). The part-time category therefore comprises faculty with a 
wide range of workloads, all of which are less than $100 \%$ of the normal workload. This categorization obscures differences between part-time faculty (e.g., faculty teaching one course are combined with faculty carrying $80 \%$ of a normal teaching load). Despite this draw back, this approach created a consistent definition of workload. This consistent definition was important because workload definitions varied between institutions and it was necessary for institutional data to be comparable.

Table 2 outlines the number and proportion of part-time appointments in Alberta's colleges and technical institutes. As of September $1999,44.0 \%$ of all faculty were part-time although this average masks substantial variation by institution.

Table 2 shows that the use of part-time faculty is greater in large urban centres and in institutions located in the more heavily populated southern parts of Alberta. This pattern may reflect a larger pool of potential part-time instructors in these areas.

\section{Limited-term employment in Alberta's colleges and institutes}

As noted above, most studies of non-regular instructional appointments do not explicitly differentiate between issues of workload and employment duration. Most frequently, part-time employees are assumed to be temporary and full-time employees are assumed to be permanent. Anecdotal evidence suggested that this assumption did not hold true in Alberta; therefore, the issue of employment duration was also examined.

In this study, faculty members were classified as permanent employees (i.e., having employment contracts without a fixed date of termination) or limited-term employees (i.e., having one or more employment contracts with a fixed date of termination). The limited-term category therefore comprises faculty with differing contract lengths but all of which have a fixed date of termination. This categorization obscures differences between limited-term fäculty (e.g., faculty with three-month contracts are combined with faculty with three-year contracts). Despite this drawback, this approach created a consistent definition of employment duration. This was important because institutions' differing definitions of faculty (based upon their degree of permanency) confounded the analysis and it was necessary for institutional data to be comparable. 
Table 2

\section{Part-time Appointments by Institution, September 1999}

\begin{tabular}{|c|c|c|c|}
\hline Institution & Total faculty & $\begin{array}{l}\text { Part-time } \\
\text { faculty }\end{array}$ & $\begin{array}{l}\text { Percentage faculty } \\
\text { part-time }\end{array}$ \\
\hline $\mathrm{ACAD}$ & 95 & 50 & 52.6 \\
\hline Bow Valley & 156 & 24 & 15.4 \\
\hline Fairview & 84 & 17 & 20.2 \\
\hline Grande Prairie & 153 & 32 & 20.9 \\
\hline Grant MacEwan & 930 & 705 & 75.8 \\
\hline Keyano & 119 & 16 & 13.5 \\
\hline Lakeland & 122 & 29 & 23.8 \\
\hline Lethbridge & 614 & 466 & 75.9 \\
\hline Medicine Hat & 177 & 76 & 42.9 \\
\hline Mount Royal & 514 & 281 & 54.7 \\
\hline NAIT & 884 & 191 & 21.6 \\
\hline NorQuest & 142 & 15 & 10.9 \\
\hline Northern Lakes & 95 & 1 & 1.1 \\
\hline Olds & 100 & 17 & 17.0 \\
\hline Portage & 106 & 29 & 27.4 \\
\hline Red Deer & 266 & 70 & 26.3 \\
\hline SAIT & 881 & 369 & 41.9 \\
\hline Total & 5,438 & 2,388 & 44.0 \\
\hline \multicolumn{4}{|c|}{$\begin{array}{l}\text { and Northern Lakes Colleges is from February 2000. Data } \\
\text { llege is from March } 2000 .\end{array}$} \\
\hline
\end{tabular}


It is important to note that faculty employed on a limited-term contract may be employed either part-time or full-time. For example, a number of institutions hire faculty to teach a full course load on a three-year contract. These faculty would be full-time when described in terms of workload but limited-term when described in terms of employment duration. Similarly, a small number of faculty are employed on a half-time basis (i.e., are part-time) but have contracts without fixed termination dates (i.e., are permanent).

Rhoades (1998) argues that the substitution of limited-term for permanent appointments may reduce the power and autonomy of faculty. Specifically, managers may be better able to bypass traditional checks on their power, more closely direct the activities of faculty members, and separate curriculum development from delivery. Overall, this strategy has the effect of subordinating faculty in institutional decision-making. The growing use of limited-term faculty also allows managers to mitigate institutions' asymmetrical ability to expand (easy) and contract (difficult) programs when the majority of faculty are full-time and permanent faculty.

Table 3 outlines the number and proportion of limited-term appointments in Alberta's colleges and technical institutes. As of September $1999,50.4 \%$ of faculty were limited-term although this average masks substantial variation by institution.

Table 3 shows that the use of limited-term faculty is more pronounced in large urban centres and in institutions located in the more heavily populated southern parts of Alberta. Again, this pattern may reflect the larger pool of potential limited-term faculty and perhaps an unwillingness of potential faculty to move to more remote locations for temporary positions. Overall, institutions use more limited-term faculty than they do part-time faculty.

\section{The overall employment of part-time and limited-term faculty}

As noted above, $44.0 \%$ of faculty in Alberta's colleges and institutes held part-time appointments in September 1999. Slightly more than half of faculty $(50.4 \%)$ held limited-term appointments. When these data 
Table 3

\section{Limited-term Appointments by Institution, September 1999}

Institution

ACAD

Bow Valley

Fairview

Grande Prairie

Grant MacEwan

Keyano

Lakeland

Lethbridge

Medicine Hat

Mount Royal

NAIT

NorQuest

Northern Lakes

Olds

Portage

Red Deer

SAIT

Total
Total faculty

$\begin{array}{cc}\text { Limited-term } & \text { Percentage faculty } \\ \text { faculty } & \text { limited-term }\end{array}$

95

49

51.6

156

17

10.9

84

28

33.3

153

52

34.0

930

745

80.1

119

11

9.2

122

39

32.0

614

413

67.3

177

107

60.5

514

328

63.8

884

256

29.0

142

36

25.4

95

7

7.8

100

28

28.0

106

29

27.4

266

102

38.4

881

495

56.2

5438

2742

50.4

Source: Institutions' human resource departments

Note: $\quad$ Data for Portage and Northern Lakes Colleges is from February 2000. Data for Fairview College is from March 2000. 


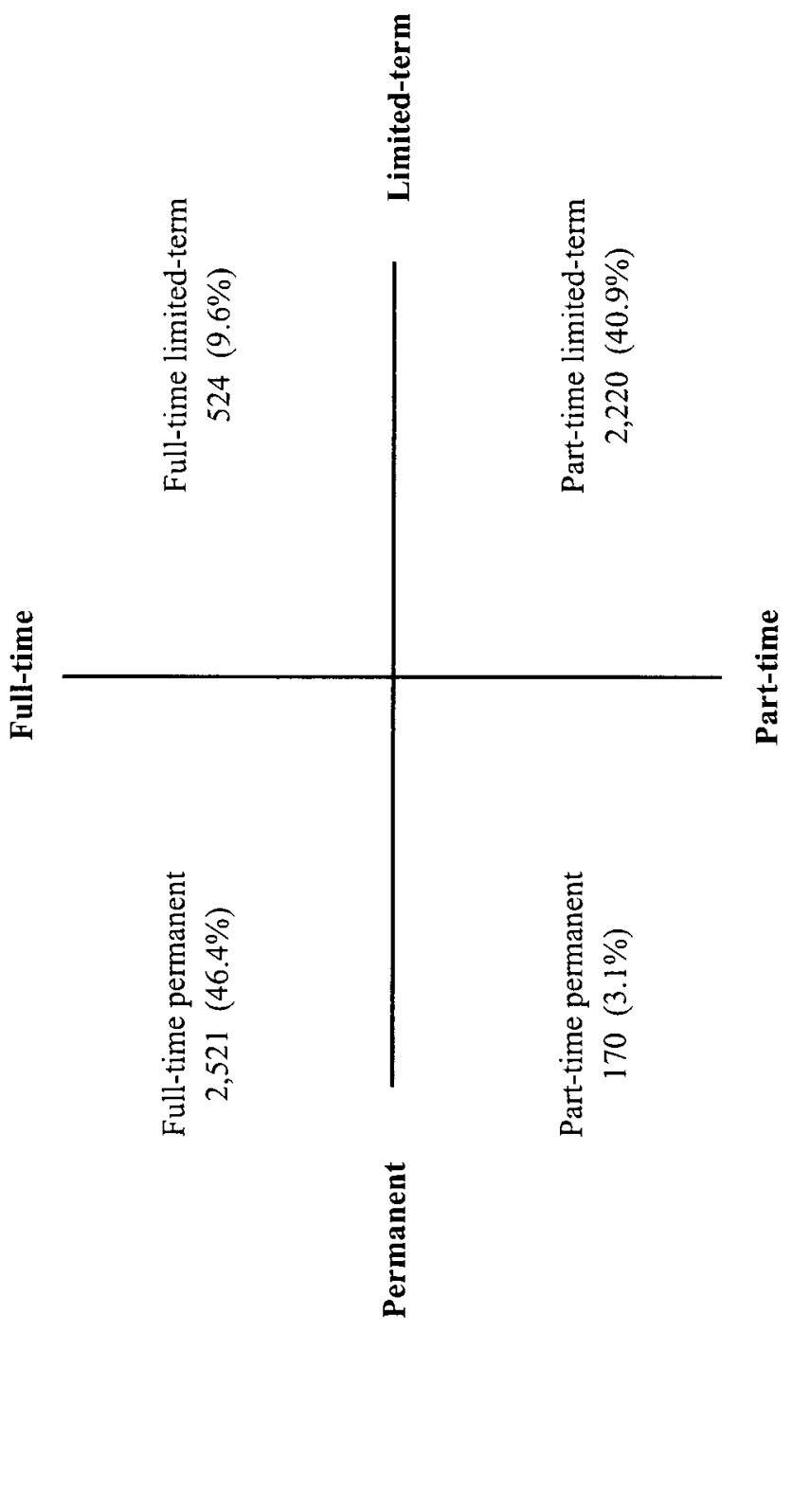

The Canadian Joumal of Higber Education Volume XXXI, No. 2, 2001 
about workload and employment duration are combined, four groupings emerge as shown in Figure 1.

The largest group of employees comprises full-time, permanent faculty $(46.4 \%)$. These employees have the highest level of remuneration, job security and opportunity for advancement. The second largest group of employees are part-time, limited-term faculty (40.9\%). These employees have the lowest levels of remuneration, job security and opportunity for advancement. The third largest group of employees are full-time, limited-term faculty $(9.6 \%)$. The final group of employees (part-time permanent faculty) is so small $(3.1 \%)$ as to be of little consequence. Of interest was that nearly 1 in 5 full-time faculty are employed on a temporary basis; that is, despite having a full-time workload, the length of their employment is fixed. This finding suggests that examining both workload and employment duration does provide a more complete picture of employment patterns.

\section{Do women disproportionately receive NRIAs?}

Concern was raised prior to commencing this study that women disproportionately received part-time and/or limited-term appointments. During the literature review, some evidence emerged that the allocation of NRIAs is related to gender. For example, a 1992 study conducted in British Columbia's colleges and institutes found $57 \%$ of NRIAs were held by females and $41 \%$ by males with $2 \%$ not reporting gender (CIEA, 1992). Frequently, gender differences are explained as the result of female faculty desiring part-time employment to accommodate childcare as well as quasi-retirement and/or other employment (Gappa \& Leslie, 1997). Two studies challenge this explanation. The B.C. study found that $55 \%$ of non-regular faculty desired more work (CIEA, 1992). A study of US two-year colleges found that $43.5 \%$ of women (as compared to $35.1 \%$ of men) in vocational fields and $63.8 \%$ of women (as compared to $62.9 \%$ of men) in liberal arts fields took part-time positions because a full-time position was not available (Benjamin, 1998). Further, this explanation would not address a gender inequity in limited-term appointments. It seems unreasonable to assume that anyone would choose to have little or no job security (an arrangement that benefits only 
institutions). The B.C. study found $84 \%$ of non-regular faculty desired more job security.

Table 4 shows the percentages of men and women holding part-time and limited-term appointments. As of September 1999, 53.4\% of women held part-time appointments (as compared to $36.4 \%$ of men) while $59.1 \%$ of women held limited-term appointments (as compared to $44.0 \%$ of men).

The data presented in Table 4 show that a greater proportion of women than men hold part-time appointments and limited-term appointments. It may that women more frequently hold part-time appointments for a host of valid reasons (e.g., child- or elder-care, quasi-retirement). Of interest is that $59.1 \%$ of women (as opposed to $44.0 \%$ of men) hold limited-term appointments. No obvious explanation exists for this difference as it is possible for women to be employed on a part-time, permanent basis. That women disproportionately hold part-time and limited-term appointments which provide lower levels of remuneration, job security and opportunity for advancement suggests some of Alberta's colleges and institutes may be violating Alberta's Human Rights, Citizenship and Multiculturalism Act that prohibits discrimination against identifiable groups such as women. Discrimination need not be direct (e.g., not hiring women) in that policies or actions that consistently yield prohibited consequences (i.e., systemic or indirect discrimination) are also a violation of human rights legislation (McPhillips \& England, 1995).

\section{The existence of a dual labour market}

Academic employment often exhibits the characteristics of a dual or segmented labour market (Gappa \& Leslie, 1993, 1997). In dual labour markets, employment is stratified into two sectors (e.g., full-time and permanent appointments versus part-time and/or limited-term appointments) that receive markedly different remuneration, job security and opportunity for advancement (Ryan, 1981).

In general, the primary labour market is characterized by high wages, good working conditions, employment stability and job security, due process in the administration of work rules, 
Table 4

NRIAs by Gender and Institution, September 1999

\begin{tabular}{|c|c|c|c|c|}
\hline \multirow[t]{2}{*}{ Institution } & \multicolumn{2}{|c|}{ Part-time } & \multicolumn{2}{|c|}{ Limited-term } \\
\hline & $\%$ Females & $\%$ Males & $\%$ Females & $\%$ Males \\
\hline $\mathrm{ACAD}$ & 55.6 & 50.8 & 55.6 & 49.2 \\
\hline Bow Valley & 16.0 & 12.9 & 12.0 & 6.5 \\
\hline Fairview & 42.1 & 13.9 & 63.2 & 19.1 \\
\hline Grande Prairie & 26.5 & 16.5 & 36.8 & 31.8 \\
\hline Grant MacEwan & 77.3 & 73.7 & 81.3 & 78.4 \\
\hline Keyano & 26.7 & 5.4 & 11.1 & 8.1 \\
\hline Lakeland & 41.2 & 11.3 & 45.1 & 22.5 \\
\hline Lethbridge & 84.1 & 67.6 & 74.0 & 60.6 \\
\hline Medicine Hat & 50.0 & 36.8 & 64.6 & 56.8 \\
\hline Mount Royal & 58.0 & 50.4 & 67.1 & 59.7 \\
\hline NAIT & 28.5 & 19.8 & 39.2 & 26.2 \\
\hline Northern Lakes & 2.2 & 0.0 & 6.5 & 9.1 \\
\hline NorQuest & 10.5 & 10.6 & 23.2 & 29.8 \\
\hline Olds & 11.5 & 18.9 & 34.6 & 25.7 \\
\hline Portage & 34.0 & 20.8 & 28.3 & 26.4 \\
\hline Red Deer & 32.5 & 21.0 & 49.6 & 28.7 \\
\hline SAIT & 63.4 & 34.4 & 75.8 & 49.4 \\
\hline $\begin{array}{ll}\text { Source: } & \text { Institutio } \\
\text { Note: } & \text { Data for } \\
& \text { Data for }\end{array}$ & $\begin{array}{l}\text { an resource de } \\
\text { and Northern } \\
v \text { College is fro }\end{array}$ & $\begin{array}{l}\text { artments. } \\
\text { akes College } \\
\text { March } 200\end{array}$ & is from Februc & $y 2000$. \\
\hline
\end{tabular}

and opportunity for advancement. This contrasts with the secondary market that features low wages, poor working conditions, considerable variability in employment, harsh and often arbitrary discipline and little opportunity to advance. The most significant distinction between the two markets is the discrepancy in job stability and security. In the secondary labour market, workers face substantial instability in employment and their jobs are not connected to any occupational ladder... Wages in the primary sector reflect, among other factors, years of employment, cost of living adjustments, and performance incentives, whereas wages in the secondary 
sector respond primarily to the aggregate balance of supply and demand. (Roemer \& Schnitz, 1982, p. 522)

A dual labour market can have a number of consequences, including the secondary labour market organizing to promote its interests at the expense of members of the primary labour market and even the broader organization (Roemer \& Schnitz, 1982). Further, the existence of a secondary labour market may actually erode the position and size of the primary labour market (Gappa \& Leslie, 1993).

The collective agreements of the seven institutions with greater than $25 \%$ of their faculty employed on a part-time and limited-term basis were reviewed to explore the differences in employment conditions (e.g., salary, benefits, and opportunity for advancement) between full-time, permanent faculty and those holding NRIAs (ACAD, 1997; GMCC, 1997; LCC, 1997; MHC, 1997; MRC, 1998; RDC, 1995; SAIT, 1997). Prior to presenting the data, it is important to note some limitations.

It is extremely difficult to compare the employment conditions of full-time, permanent faculty with those of faculty holding NRIAs because full-time, permanent faculty have administrative and curricular responsibilities as well as instructional duties. Further, comparing workloads between different academic areas (e.g., trades versus university transfer) is often problematic with institutions enacting complex "standardized academic unit" calculations to address this issue internally. These difficulties compound when inter-institutional comparison is undertaken. This study attempts to deal with this limitation by making salary comparisons on a per-course basis. That is, the salary paid to a full-time, permanent instructor is prorated on a per-course basis (assuming most faculty teach the equivalent of 10 one-semester courses per academic year) and compared to the per-course pay received by NRIAs. As noted above, this classification fails to address the differing duties of full-time, permanent faculty and the faculty holding NRIAs. Despite this drawback, a per-course comparison provides the most reasonable means by which to compare salary at a provincial level. Somewhat mitigating this drawback is that faculty holding NRIAs often perform curricular and administrative duties without pay. 
Differences in contract language create further limitations. The working conditions of NRIAs at many institutions are not codified or are vaguely worded and attempting to determine benefits levels and holiday provisions often requires inference. This variance limits the validity of the comparisons presented below and they should be cited with caution (or, preferably, with reference to the collective agreement from which they are drawn). A related third limitation is that not all faculty holding NRIAs within a single institution have similar employment conditions. Some NRIAs are identical to full-time, permanent appointments (e.g., sessionals) except that they are employed on a temporary basis. These same institutions may also have one or more categories of part-time and/or limited-term faculty. When combined with the vague (or absent) contract language, this makes inter-institutional comparisons difficult. For the purpose of this comparison, the NRIA used for comparisons was the NRIA that received the highest level of remuneration but was not a limited-term version of a full-time, permanent appointment (i.e., was not a sessional appointment). Permanent, part-time positions were also excluded as they exist primarily to accommodate full-time, permanent faculty desiring flexibility. Finally, it is important to note that examining the collective agreements does not fully capture the working conditions faced by NRIAs. Specifically, the collective agreements do not address the treatment of faculty holding NRIAs, their motives for teaching, and how their different employment conditions affect them.

Table 5 indicates that, at five of seven institutions, faculty holding NRIAs received less pay on a per-course basis. The difference in pay ranges from $\$ 0$ to $\$ 3,145$.

The comparisons between the pay of full-time, permanent faculty and that of faculty holding NRIAs presented in Table 5 may be slightly misleading. In most cases, NRIAs will be paid closer to the minimum level while most full-time, permanent faculty are paid closer to the maximum level (reflecting that experience is less frequently considered in remuneration of the secondary labour market). In the most extreme cases, NRIAs are paid between $\$ 2,526$ and $\$ 4,201$ less per course than full-time, permanent faculty. It is important to note the limitations affecting this finding that are outlined above. 


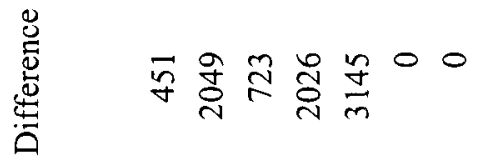

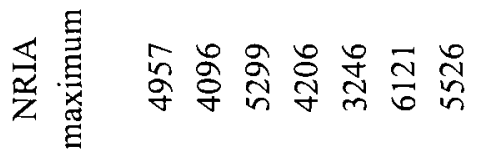

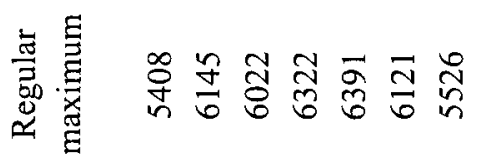

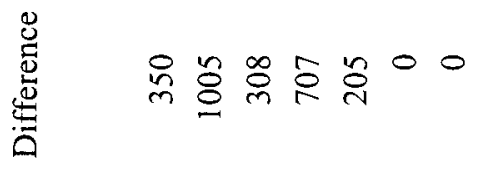

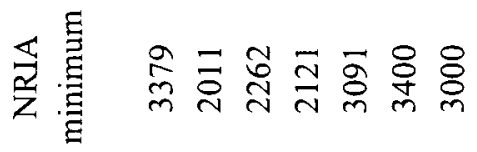

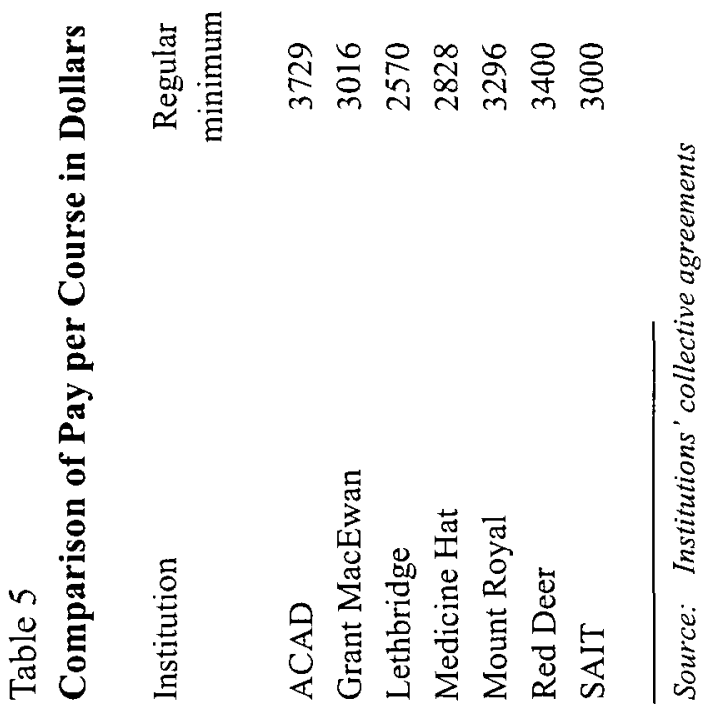


It is not possible to compare the benefit levels of NRIAs with those of full-time faculty. In part, this is because the specifics of benefits are frequently not contained within the collective agreements. It is possible to get some sense of the job security and opportunity for advancement that NRIAs have at the seven institutions noted above. The nature of limited-term appointments suggests that faculty holding them have no job security beyond the end of their current contract. At all institutions, faculty holding NRIAs can access the grievance process (although faculty holding NRIAs at Lethbridge Community College are precluded from taking grievances to arbitration). That said, there is a strong sense among grievance officers that faculty with limited-term appointments who file grievances risk the non-renewal of their contract (Sway, 2000). Both Red Deer College's and SAIT's collective agreements cap in some manner the number of faculty who can hold NRIAs. Experience to date, however, indicates that these caps are difficult to enforce (Logue, 2000). Grant MacEwan Community College's collective agreement requires a review of the classification of faculty holding NRIAs after three years of employment but the decision to reclassify lies with the dean. All institutions have a provision for part-time permanent appointments but experience to date suggests that these appointments are reserved for full-time, permanent faculty wishing a temporary reduction in their workload (Sway, 2000).

\section{DISCUSSION}

This study raises a number of interesting and difficult questions for faculty members in Alberta's colleges and institutes. For example, how did the dual labour market that exists at five institutions come about? What political and legal implications do the large number of faculty holding NRIAs have for faculty associations? A number of broader implications of this trend are also discussed.

\section{How did a dual labour market emerge?}

It seems reasonable to assert that declining government funding pressures institutions to reduce instructional costs by increasingly using 
part-time and limited-term appointments. The ability of institutions to make non-regular instructional appointments can be (and is at some institutions) constrained by the collective agreement. This agreement is developed and modified jointly by an institution's Board of Governors and its faculty association. If a collective agreement allows an institution to hire a large (or unlimited) number of part-time and limited-term faculty, this contract suggests that the faculty association (traditionally dominated by full-time and permanent faculty) was unable and/or unwilling to negotiate a clause to prevent this outcome.

In Prindle's (1998) examination of the use of part-time faculty at three Alberta colleges, she found that full-time, permanent faculty interviewed focused on maintaining their remuneration, job security and opportunity for advancement while the number of NRIAs increased.

Faculty Associations often formed coalitions within their membership of full-time, continuing instructors with instructors who were close to full-time in status, such as sessionals. This coalition would bargain for better salaries and benefits for these two groups sometimes to the detriment of the greater number of part-time instructors... Faculty Association interviewees, in almost all instances, seemed to be more concerned with maintaining the status quo and not eroding their base of full-time membership. Association members interviewed realized the inequities of treatment for part-time instructors, but were still more interested in negotiating their way through changing circumstances for full-time, their longterm members, at their own institutions than they were in picking up a whole new group of employees to represent (pp. 134-135).

Overall, faculty members (mainly full-time) see nothing to gain, and security, seniority and professional development funds to lose, from breaking from the tradition of advocating for full-time members (p. 158).

When this evidence is combined with the absence of controls on hiring NRIAs in the collective agreements, it suggests that full-time permanent faculty have (intentionally or inadvertently) facilitated the growing use of part-time and limited-term faculty. 


\section{What political and legal implications does this have for faculty associations?}

At the Grant MacEwan College, Lethbridge Community College and Mount Royal College, the number of faculty holding NRIAs is now larger than the number of full-time, permanent faculty. This percentage creates a situation wherein the political stability of the faculty association is no longer assured. Assuming faculty holding NRIAs could overcome organizational difficulties, their numbers would allow them to assume control of the association (and, thus, the bargaining of future collective agreements). This has the potential to alter how remuneration is distributed drastically as well as disrupt the smooth functioning of the organization.

From a legal perspective, if faculty associations bargain collective agreements that consistently disadvantage faculty holding NRIAs, they may be failing in their duty of fair representation. The duty of fair representation requires that faculty associations not act unfairly, arbitrarily or discriminatorily towards their members (Thorncroft \& Eden, 1995) such as by negotiating contracts that consistently yield poorer employment conditions for part-time and/or limited-term faculty. Failing to address this issue may result in faculty holding NRIAs pursuing remedy through the court system.

\section{Broader implications}

The differences between provincial college sectors make it unreasonable to generalize the conclusion of this study to other jurisdictions. This study does, however, raise a number of interesting questions with application beyond Alberta. For example, what impact will the expected shortfall of qualified faculty at universities have as retirements coincide with an enrollment increase (Frank, 2000; Laurier Institute 2000; Smith 2000)? Will universities draw faculty from community college university-transfer programs? The higher salary levels, lower teaching loads and the opportunity to conduct research offered by universities may make this an attractive option for some college instructors. Similarly, will the expected shortfall in skilled tradespeople and managers draw current and potential faculty away from careers in college and institutes? 
Further, will these changes in the academic labour market create pressure on institutions to improve the terms and conditions of employment?

As discussed previously by Rhoades (1998), a second set of implications centre on the impact of the growing use of NRIAs on the power and control administrators can exercise both inside and outside of the classroom. The nature of education makes it difficult for administrators to assert their right to manage because individual instructors retain control over the activity in the classroom (and, in fact, educational outcomes stem from faculty's interaction with students). Nevertheless, NRIAs can increase productivity because faculty holding NRIAs cost less on a percourse basis than full-time, permanent staff and allow institutions to extract additional labour from their employees. Institutions can extract additional labour from NRIAs because of the disparity in power between employers and faculty holding limited-term appointments: although the notion of a "contract" between a faculty member and an institution implies two (relatively equal) parties voluntarily entering into a relationship, this is not always the case. Benjamin (1998) notes that while NRIAs are entirely optional for some faculty (e.g., professionals teaching for prestige, intrinsic rewards or extra income), for others it is a matter of working on the employer's terms, or not working at all. Faculty hired on limited-term contracts are exceptionally vulnerable because they have no job security beyond the end of their contract. This vulnerability provides administrators with substantial leverage with which to extract additional labour (e.g., attend meetings, take part in committee work, or develop curriculum) without remuneration. Faculty in this position are less likely to refuse, complain or file grievances than full-time, permanent faculty would be because of the implicit threat of nonrenewal. If collective agreements are a key tool used by faculty to constrain the actions of administrators in public colleges, the growing use of faculty who are poorly (or not) protected suggests administrators gain additional operational latitude. 


\section{References}

ACAD. (1997). Collective agreement between the Board of Governors of the Alberta College of art and Design and the Alberta College of Art and Design Faculty Association. July 1, 1997-June 30, 2000. Calgary, AB: Alberta College of Art and Design.

AECD. (1994). New directions for adult learning in Alberta. White Paper. Edmonton, AB: Advanced Education and Career Development.

AECD. (1995). 1994/95 Annual report. Edmonton, AB: Advanced Education and Career Development.

AECD. (1999). 1998/99 Annual report. Edmonton, AB: Advanced Education and Career Development.

Alberta Learning. (2000). 1999/2000 Annual report. Edmonton, AB: Author.

Barnetson, B. (2000). The use of part-time and limited-term faculty in Alberta's colleges and institutes. Edmonton, AB: Alberta Colleges \& Institutes Faculties Association.

Barnetson, B. \& Boberg, A. (2000). Resource allocation and public policy in Alberta's higher education system. The Canadian Journal of Higher Education, 30(2), 57-86.

Benjamin, E. (1998). Variations in the characteristics of part-time faculty by general field of instruction and research. In D.W. Leslie (Ed.), The growing use of part-time faculty: Understanding causes and effects. New Directions for Higher Education, 104, 45-59.

CIEA. (1992). Non-regular faculty survey. Report. Vancouver, BC: College Institute Educators' Association Committee for Non-Regular Faculty.

Council of Ontario Universities. (1991). Non-regular instructional personnel in Ontario Universities. Report, June. Toronto, ON: The COU Committee on the Status of Women.

Dennison, J.D. (1995). Organization and function in postsecondary education. In J.D. Dennison (Ed.), Challenge and opportunity: Canada's community colleges at the crossroads, (pp. 13-104). Vancouver, BC: UBC Press.

Dennison, J.D., \& Gallagher, P. (1986). Canada's community colleges: A critical analysis. Vancouver, BC: UBC Press.

Frank, T. (2000). Competition for faculty heats up. University Affairs, January $8,10-12$.

Gappa, J.M., \& Leslie, D.W. (1993). The invisible faculty. San Francisco, CA: Jossey-Bass. 
Gappa, J.M., \& Leslie, D.W. (1997). Two faculties or one? The conundrum of part-timers in a bifurcated work force. New Pathways: Faculty, career and employment for the 21 st century working paper series. American Association for the Advancement of Science. Washington, DC: ERIC Document Reproduction Service, ED 424817.

GMCC. (1997). Collective agreement between the Grant MacEwan Community College Board of Governors and the Grant MacEwan Community College faculty Association. Edmonton, AB, July 1, 1997 to June 30, 1999.

Laurier Institute. (2000). Renewal and retention: Attracting and keeping faculty and senior administrators at British Columbian University. Report, June. Vancouver, BC: Author.

LCC. (1997). Collective agreement between the Board of Governors and Faculty Association (revised). Lethbridge, July 1, 1997 to June 30, 1999.

Leslie, D.W. (Ed.). (1998). The growing use of part-time faculty: Understanding causes and effects. New Directions for Higher education, 104.

Leslie, D.W, Kellams, S.E., \& Gunne, G.M. (1982). Part-time faculty in American higher education. New York, NY: Praeger.

Logue, E. (2000). Personal communications. Ed Logue, President, SAIT Academic Staff Association.

Lundy, K.L.P., \& Warme, B.D. (1985). Part-time faculty: Institutional needs and career dilemmas. Paper presented at the 1985 ASHE Annual Meeting, Chicago, March 16. Washington, DC: ERIC Document Reproduction Service, ED 259613.

McPhillips, D., \& England, G. (1995). Employment legislation. In M. Gunderson \& A. Ponak (Eds.), Union-management relations in Canada, 3rd edition, (pp. 73-102). Don Mills, ON: Addison-Wesley Publishers Limited.

MHC. (1997). Contract between the Faculty Association and the Board of Governors. Medicine Hat, AB, July 1, 1997 to June 30, 1999.

MRC. (1998). Collective agreement between the Mount Royal Faculty Association and the Board of Governors of Mount Royal College. Calgary, AB, July 11997 to June 30, 1999.

Prindle, L.M. (1998). Part-time instructors and organizational change in three community colleges in Alberta, Canada. Unpublished doctoral dissertation. Gonzaga University, WA, School of Education.

Rajagopal, I., \& Farr, W.D. (1989). The political economy of part-time academic work in Canada. Higher Education, 18, 267-285.

Rajagopal, I., \& Lin, Z. (1996). Hidden careerists in Canadian universities. Higher Education, 32, 247-266. 
RDC. (1995). FARDC/Board Collective Agreement. Red Deer, AB, July 1, 1995 to June $30,1998$.

Rhoades, G. (1998). Managed professionals: Unionized faculty and restructuring academic labour. Albany, NY: State University of New York Press.

Robinson, P. (1994). Part-time faculty issues. Washington, DC: American Federation of Teachers.

Roemer, R.E., \& Schnitz, J.E. (1982). Academic employment as day labour: The dual labour market in higher education. Journal of Higher Education, 53(5), 514-531.

Roueche, J.E., Roueche, S.D., \& Milliron, M.D. (1995). Strangers in their own land: Part-time faculty in American Community Colleges. Washington, DC: American Association of Community Colleges.

Ryan, P. (1981). Segmentation, duality and the internal labour market. In F. Wilkinson (Ed.), The dynamics of labour market segmentation, (pp. 3-22). Toronto, ON: Academic Press.

SAIT. (1997). Collective agreement between the Board of Governors of the Southern Alberta Institute of Technology and the SAIT Academic Faculty Association. Calgary, AB: Author.

Smith, D.C. (2000). Will there be enough excellent profs? Report on prospective demand and supply conditions for university faculty in Ontario. Report, March. Toronto, ON: Council of Ontario Universities.

Statistics Canada. (2000a). Full-time and part-time employment. CANSIM Matrix 3472. www.statcan.ca

Statistics Canada. (2000b). Educational staff of community colleges and vocational schools. The Daily, September 13. www.statcan.ca.

Sway, T. (2000). Personal communication. Terry Sway, Labour Relations Officer, Alberta Colleges \& Institutes Faculties Associations.

Thorncroft, K.W., \& Eden, G. (1995). Grievances and their resolution. In M. Gunderson \& A. Ponak (Eds.), Union-management relations in Canada, 3rd edition, (pp. 255-280). Don Mills, ON: Addison-Wesley Publishers Limited.

Tuckman, H. (1978). Who is part-time in academe? AAUP Bulletin, 64. 305-315. 